\title{
DEBT TARGETS AND FISCAL RULES PRACTICES ON PUBLIC DEBT FOR TURKEY
}

\author{
Binhan Elif YILMAZ ${ }^{1}$
}

\author{
Sinan ATAER ${ }^{2}$
}

\begin{abstract}
Debt targets act as an anchor of fiscal policies and ensure the sustainability of fiscal policy, provide a sufficient policy room for the economic stabilization policies in order to challenge adverse shocks. Prudent debt targets decrease the risk premia and cost of the active fiscal policies by ensuring the environment of confidence which the markets need. Prudent debt targets are set according to the economic situation of countries and in the frame of fiscal rules. For the purpose of obtaining results in compliance with these targets, fiscal rules have two main objectives. The first objective is contributing fiscal discipline and the second one is enabling the stabilization policies. However, achieving these targets is not only subject to debt-related fiscal rules. Expenditures revenues related to fiscal rules have to be used in harmony with the debt related fiscal rules.

In our study, we are going to try to ask these questions; what are the prudent debt targets for the short-mid and long terms, how to design fiscal rules and general fiscal framework to survive economic fluctuations. These questions will be tried to answer in the frame of the public debt performance and traditional fiscal policies of Turkey. In this study, a set of policy offers will be tried to developed to provide a functional role for the living through Turkey from the current economic fluctuation with the independent economic stabilization policies.
\end{abstract}

Keywords: Debt Target, Fiscal Rule, Debt Ceiling, Debt Tolerance, Prudent Debt Target, Fiscal Policy

JEL Code: F34, F37, H6.

\section{Introduction}

It is possible to divide the concepts of restrictions to the governments related public borrowing as; the ones that determined by the economic indicators in the nature of the economy and the ones that are human-made restrictions by the legislative way. In this case, there may be economic sanctions of crossing the line of the restrictions determined by the economic indicators. In contrast, the restrictions brought by the legislation may be detected by the control mechanism in the states and impose sanctions with the hand of judicial mechanism or with the systems which occurred by the governments. The more strict mechanisms bring less frequency of limit excess. If these mechanisms are advisory or give notice of the situation, the frequency of limit excess may increase.

In this study, among the mentioned restrictions; debt limit, debt target and debt ceiling concepts will be examined, and the situation of Turkey in terms of public debt management will be handled in the light of these concepts.

The research questions generated by this study, may be handled by the empirical analysis methods in the next studies. It is believed that this study will be beneficial for other researchers to study borrowing issues with the help of these restrictive concepts.

\footnotetext{
1 Prof. Dr., Istanbul University, binhan@istanbul.edu.tr

2 Res. Assist., Istanbul Medeniyet University, sinan.ataer@medeniyet.edu.tr
} 


\section{Public Debt Management and Public Debts as a Tool of Fiscal Policy}

The government borrowing beyond all economic debates, stands in front of us as a social choice. A public authority, while finding the financial resources needed to the production of public goods and services, is obliged to choose one of those; using resources collected as tax revenues or using resources obtained from borrowing. This choice determines that if the price of the public goods and services paid by their users or the next generations of their users.

In his two different papers, Robert J. Barro $(1974,1979)$, explains Ricardian Equivalence Theory as a systematic way. Barro asserts that, the borrowing of the government instead of collecting taxes, will be noticed by the rational individuals and then rational individuals start to save money to make easier to pay the higher taxes by their next generations and at the end, there will be no different economic results of making a choice between collecting taxes and borrowing.

However, in the cases which have deviations from the assumptions of Barro, in other words in an economy which has no altruist individuals, there will be different economic effects of the results of the public debts and the taxes. In fact, there are studies give exact opposite results with Barro in the literature of behavioral economics. In an experimental study, that was shown, in the cases of that is possible to transfer the tax load to the next generations, participants have demanded more public goods and services. In the opposite case which they can not transfer the tax load, participants have demanded less public goods and services (Fochmann vd., 2018).

When it comes to this kind of choice, more than one variable as economic, social and politic, affects the decision of the public authority. Once we accept that the borrowing is not a choice but a necessity in an economy which is externally open and desires remain competitive in terms of growth, we can start to talk about how borrowing policies that the governments should apply.

The public debt management takes the realization of borrowing as the zero points and covers the borrowing strategies before borrowing as well as the debt services after the borrowing. Ideally it is foreseen that the government should borrow from various resources with the low costs and with the longest term possible. Of course the costs and maturities of debts have related the confidence between the lender and borrower about the service of the debt. The borrower countries cannot always apply the lenders under the perfect circumstances so that is not always possible to borrow with the lowest costs and long terms. The debts with short terms and high costs, which are not well planned and regulated within the particular strategic forecasts may be connected with other external shocks and may cause debt crisis.

The 2011 European Debt Crisis can be shown as an example from the near past for the experienced debt crisis. One of the basic questions of our study; "What should be the prudent debt target?" came under the light at that point. How the member states of the European Union, has maintained high debt levels despite the written fiscal rule of Maastricht Criteria which demand the Public Debt / GDP ratio under $60 \%$ and invited the crisis into Europe? This may be the subject of a different study.

Another decision-making process which government should conduct, is choosing the internal debt or external debt resources. This preference generates different results in the countries' economies, so to make the right choice, economic circumstances must be evaluated widely. For instance, if there is a liquidity shortage in the country, borrowing from internal resources may cause a recession. That is why borrowing is a fiscal policy tool at the same time. In the inflationist times, internal debts run as a stabilizer by reducing pressure on the price levels and create an upright effect for the economic growth in the future by increasing internal savings. 
In this point, a debt ceiling or a prudent debt target comes in front of us. Because keeping the public borrowing as a fiscal policy tool is dependent on keeping a "fiscal space" which allows using public borrowing as a stabilizer.

\section{The Fiscal Rules Related Public Debts, Prudent Debt Targets and Other Restrictions}

First of all we need to specify that the debt ceiling applications have a history for almost a hundred years. Periodically, there have been times which these applications conducted strictly or left completely. However, debt ceiling application is not a concept which there is a consensus on it in the public economics literature and there are many doubts about its efficiency.

The first debt ceiling crisis in history was experienced in the United States in 1953. The United States faced the excessing risk about the debt ceiling. Against this risk, the administration of that period had taken some measurements as reducing expenditures and gold monetization but eventually they had to increase the debt ceiling (Garbade, 2016: 1).

The studies about the debt ceiling have been added to agendas after the 2011 European Debt Crisis which showed that in the countries which have high levels of public debt, the real or financial shocks may lower the credibility and cause the risk of nonredemption of debts. These primary results may drive the economies into high-interest rates cycle, credit fragility and recession (Guerson ve Meline, 2011: 4).

The OECD, published a report (OECD, 2015) as a guide about how to use the fiscal rules to set applicable prudent debt targets. According to this report, there has to be two main aim of the fiscal rules. The first one is providing fiscal discipline. The second one is enabling the stabilizing policies. Countries need to consider the mainframe of fiscal rules which are not excessively restrictive and subsequently need to set an implementable prudent debt target.

The prudent debt targets should consider the macroeconomic shocks which may affect the development of public debts. In order to minimize the risk of excessing the target which may reduce the credibility of a country, the future position of public deficits should be carefully examined. For the purpose of an accurate target setting, the progress of the public debts with the assistance of economic models (Fall vd., 2015).

According to the results of a study on Turkey (Çetin, 2018: 55), the terms with increasing public debts are followed by poor macroeconomic performance. When the prudent debt target regime is applied, in the first phase, the fiscal discipline improves by the restriction of the borrowing and in the following terms, debt and tax load decreases and the taxes with the diversion effects may be reduced. Increasing fiscal discipline decreases the inflation rate, output deficits and expenditure deficits, and has an expanding effect in the total output performance.

\subsection{Prudent Debt Targets}

We can define the prudent debt targets as the borrowing level which has to be applied in order to maximize economic growth, increasing the efficiency of the fiscal policies and increase the radius of action of the governments. 
In the OECD member developing countries as Turkey, this target is calculated as $60 \%$, due to unstable structures and openness to the external shocks, such kind of countries need to ideally set the prudent debt targets between $30 \%$ and $50 \%$.

We can count the aims of prudent debt targets as; preventing unlimited borrowing of the public authority, providing a confident environment, protecting the fiscal space, lowering the costs of risk premiums and fiscal policies.

\subsection{Debt Limits}

The debt limit expresses the level of maximum debt level which the government can not exceed. The debt limit cannot be determined by political or economic decision-making mechanisms. The main indicators of an economy; growth rates and interest rates together determine the debt limit. The sanctions are economic too. Liquidity crunch, crowding the governments out of the monetary markets, "fiscal fatigue" may occur as a result of excessing the debt limit.

According to the studies on the OECD member countries, this limit is calculated as twice as GDP. This is significant that the debt limit is not an indicator for the prudent debt targets to be set in a country.

\subsection{Debt Ceiling}

We may define the concept of debt ceiling as "the largest value of public debt that does not jeopardize long-run fiscal sustainability" (Lima et. al, 2005). But in some practices, the debt ceilings are applied as strict rules which governments should not exceed with soft applications as Turkey or more solid rules as United States.

For Turkey, the debt ceiling is set by the part of the law number 4749 as "debt, loan and guarantee limits". According to the law, in a fiscal year, by considering development, stability, confidence in markets, macroeconomic balances and fiscal sustainability, a net borrowing can be made equal as the difference between estimated incomes and the starting allowances stated in the budget law.

In the same law, there is an option to increase the debt limit for $5 \%$ in the first step and a $5 \%$ more in the second step but the second one is possible with the decision of the presidency.

This application has started in 2003 and successfully applied until the Global Crisis' affect the year 2009. After 2009, the most important deviation has seen in 2017 as twice of the debt ceiling.

\subsection{Evaluating Turkey in Terms of Public Debt Restrictions}

There are several restriction related to public debt on the governments in Turkey. In the terms of economic fluctuations we can observe that the limits or ceilings are exceeded and there are no serious sanctions against the responsibles of the public debt management. In the graphich 1 , we can see the deviations from the debt ceiling which indicated in the law number 4749. Most of the deviations are compatible with the global fluctuations but especially in 2017 there is a great amount of deviation from the debt ceiling. 


\section{Graphich 1. Deviation From Debt Ceiling in the Law Number 4749 (Million TL)}

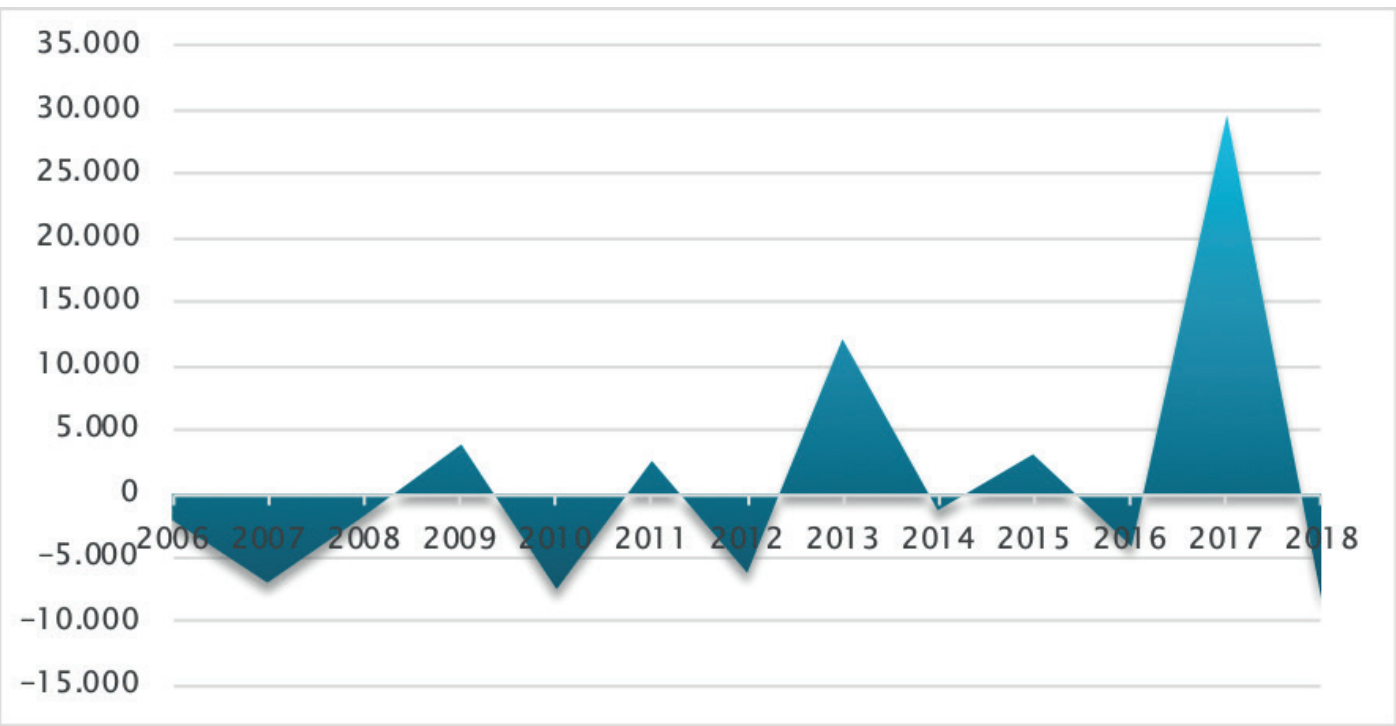

Source: Republic of Turkey Ministry of Treasury and Finance Statistics

In the Graphic 2, we can see the growth rates, produced value added public debt stock and public expenditures as percentages of gross domestic product. We may analyse that the public expenditure rates do not seem as the reasons of deviation from the public debt limits. We may find a negative and significant relationship between growth rates and public debt stock in the further empirical studies according to Graphic 2.

Graphic 2. Growt Rates, Produced Value Added, Public Debt Stock and Public Expenditures (\%)

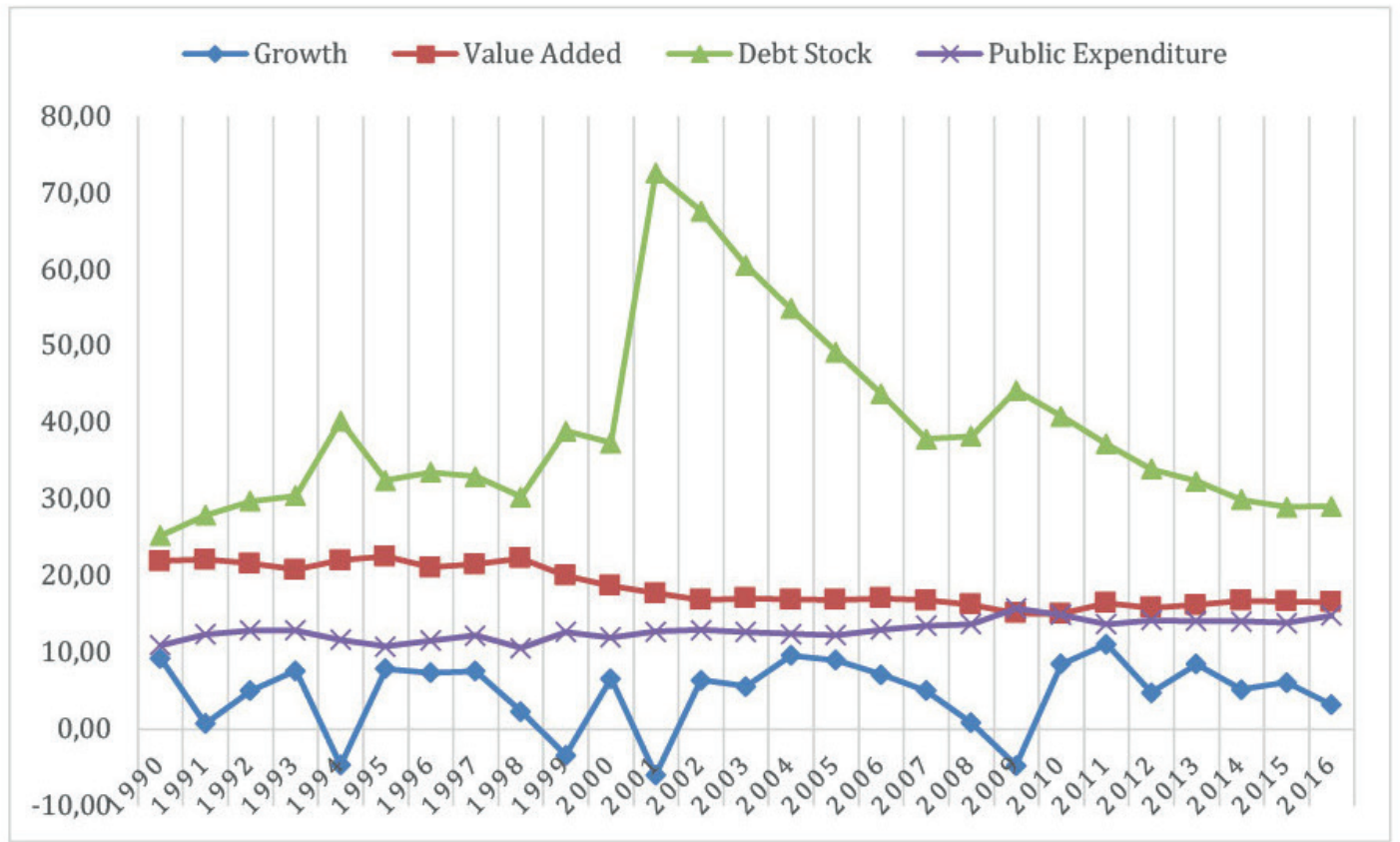

Source: Derived from World Development Indicators and Republic of Turkey Ministry of Treasury and Finance Statistics. 
Another interesting view is that Turkey can not produce increasing value added even it increase the growth rates. If the economic growth may be supported with the increasingly produced value added, Turkey would minimize or eliminate the deviations from debt limits. This issue also may be simulated in the further studies.

\section{Conclusion}

Different fiscal rules have different effects on the economy. Budget rules are not effective in the stability or flexibility but effective on the fiscal discipline as twice as the other fiscal rules. Spending rules have positive impacts on stability and flexibility but restrict the action space against risks. Income rules have effects only on the fiscal discipline and in contrast, have negative impacts stability, risks and flexibility.

The fiscal rules related to public debts restrict the results but have not any considerations on the reasons. The fiscal rules related to the budget balance restrict one of the reasons for the high level of debts but they do not restrict their own reasons.

As a policy recommendation, we suggest that the targets related production, value-added and growth in the programs and they should have economic and judicial sanctions.

The current fiscal rules' sanctions should be strengthened and their contributions to the fiscal discipline should increase.

\section{References}

Barro, J. R., (1974). "Are Government Bonds Net Wealth?", Journal of Political Economy, 82 (6), pp. 1095-1117.

Barro, J. R., (1979). "On the Determination of the Public Debt", Journal of Political Economy, Vol. 87 (5), pp. 940-971.

Çetin, İ., (2018), "Borç Hedeflemesi Rejimi ve Makroekonomik Performans", Yönetim ve Ekonomi Araşttrmaları Dergisi, 2, pp. 41-57.

Fall et al., (2015), "Prudent Debt Targets and Fiscal Frameworks", OECD Economic Policy Paper, 15.

Fochmann et al., (2018), "Two Sides of Public Debt Intergenerational Altruism and Burden Shifting", PLOS ONE, 13 (8), e0202963.

Garbade, D. K., (2016). "The First Debt Ceiling Crisis", Federal Reserve Bank of New York Staff Reports, 783.

Guerson, A., Melina, G., (2011). "Public Debt Targeting An Application to the Caribbean”, IMF Working Paper, 11/203.

International Monetary Fund. (2019). World Development Indicators Data Catalog, https:// datacatalog.worldbank.org/dataset/world-development-indicators, (02.02.2019).

OECD, (2015). "Achieving Prudent Debt Target Using Fiscal Rules", OECD Economics Department Policy Note, 28.

Lima et al., (2008), "Debt Ceiling And Fiscal Sustainability in Brazil: A Quantile Autoregression Approach", Journal of Development Economics 86, pp. 313-335.

Republic of Turkey Ministry of Treasury and Finance. (2019). Public Finance Statistics, https:// en.hmb.gov.tr/public-finance, (01.02.2019). 